\title{
Types of Integration, Acculturation Strategies and Media Use of Young Turks in Germany
}

JOACHIM TREBBE

\begin{abstract}
Although most Turks in Germany belong to the second or third generation of immigrants, they have retained the social, cultural, and religious identity of their country of origin. This article deals with this double identity of young Turks in Germany and their language-bound exposure to television, radio, press, and the Internet. Telephone survey data are presented regarding the integration and media use of Turks in Germany. The survey was carried out in 2006 on behalf of the public broadcasting station of North Rhine-Westphalia (Westdeutscher Rundfunk, WDR). The analyses identify and describe different types of integration of Turks and investigate the relationship between their level of integration and their demographic profile as well as their patterns of media use. Causal analysis was focused on the question how different strategies of acculturation influence the use of mass media.
\end{abstract}

Keywords: integration, media use, Turks, Germany, types of integration, acculturation strategies

\section{Introduction}

Turkish migrants and German citizens with a Turkish migration background are still the largest group among all ethnic minorities in Germany. In 2005 about 1.8 million Turkish migrants were living in Germany. In addition, between 1999 and 2005 about 450 thousand Turks became German citizens through naturalization (Migrationsbericht, 2005: 172-176). This category of inhabitants should appeal to migration and mass communication researchers from a scientific point of view, and applied audience researchers and ethno-marketers should also be interested. But despite their sheer quantity and economic power as entrepreneurs and customers, the Turks in Germany are neither part of the 
continuous audience ratings for radio and television nor are they included in the routine sample definition of the media use studies for the press (Müller, 2000; Windgasse, 2006).

Nevertheless, a wide-spread debate exists regarding the integration of foreigners in Germany, especially Turks. This discussion often builds on the simple (and naturally implicit) stimulus-response paradigm of the media as tool or key for successful integration. Even more often, the dysfunctional argument is used: Minority media use or the use of transnational satellite broadcasting from the country of origin supposedly leads migrants into the ethnic media ghetto and harms integration (Goldberg, 1998; Meier-Braun, 2002; Schneider and Arnold, 2006).

The following article is based upon data from a survey conducted on media use patterns of Turks in Germany. The study was carried out in 2006 on behalf of the public broadcasting station of North RhineWestphalia (Westdeutscher Rundfunk, WDR). The data will be examined here from a more recipient-oriented perspective. After presenting some basic data and sample information from the survey, a typology of integration will be presented and in some aspects compared to a previous nationwide study carried out in the year 2000 on behalf of the German government. Finally, the use of German and Turkish mass media is examined as an effect (not a cause) of the individual integration status. The theoretical model of cognitive acculturation strategies (Berry, 1980, 1997) will be used to systematize attitudes and social behavior of the Turks towards the German society. But first, we will provide a short overview of the research tradition in Germany with regard to media use of Turkish migrants in Germany.

\section{Research context: Audience research among Turkish migrants in Germany}

There exists only a short research tradition regarding media use of Turkish migrants in Germany. The first nationwide study was conducted in 1981 on behalf of the First National Broadcasting Network (Arbeitsgemeinschaft der Rundfunkanstalten Deutschlands, ARD) and the Second National Television Network (Zweites Deutsches Fernsehen, ZDF). In a face-to-face survey 3,000 participants, originating from Greece, Italy, Yugoslavia, Spain and Turkey were interviewed about their access to mass media, their daily routines of media use and the functions, motives and gratifications of media use (Eckhardt, 2000; Darkow and Eckhardt, 1982; Darkow, Eckhardt and Maletzke, 1985; Eckhardt, 1987). Two further studies followed on behalf of the WDR in 1990 (Eckhardt, 1990) and 1995 (Eckhardt, 1996), each of them representative for the German state North Rhine-Westphalia (NRW) among participants from several countries of origin, including Turkey. North Rhine-Westphalia is the 
largest state in Germany (in terms of numbers of citizens) and the state with the highest number of Turkish migrants. More than one third of the Turks in Germany live there. This explains why the WDR was one of the first public service networks in Germany that started special programs aimed at migrants, and was interested in their use and acceptance of these programs. In 2002 and 2004 the research tradition was continued with two face-to-face surveys conducted in North Rhine-Westphalia, the coverage area of the migrant radio service "Funkhaus Europa" (Windgasse, 2006). The most recent study in this field is a telephone survey among 503 Turks aged fourteen to 49, carried out in North Rhine-Westphalia (Simon and Kloppenburg, 2006; Trebbe and Weiss, 2006). The data set of the latter was made available from the WDR for scientific purposes and constitutes the basis of the analyses presented in this article.

On the national level, two surveys were conducted both on behalf of the German government, that is, the public information department (Presse- und Informationsamt der Bundesregierung, BPA). The first was carried out by the Center for Turkish studies (Zentrum für Türkeistudien, ZFT) based on a random sample from a database of 80,000 Turkish households in Germany (Gentürk, 2000; ZFT, 1996 and 1997); the second was carried out in 2000 as a face-to-face survey based on a nationwide quota sample (Trebbe, 2003; Weiss and Trebbe, 2001, 2002; Weiss, 2002).

Most of these surveys were conducted in the context of applied media research without any theoretical framework. The focus was to describe the patterns of media use in special target groups with a migration background. The aim of the two nationwide studies on behalf of the German government was also to describe media use patterns and explore communication channels for political purposes. The implicit assumption behind these descriptions was however - as mentioned earlier - the presumably strong potential and impact of the media for the individual integration of the migrants in Germany. In contrast with this implicit (and somewhat dated) point of view, a more complex but explicit model of media use and integration by migrants, especially Turks, in Germany was applied (Weiss and Trebbe, 2001: 5). Based on the assumption that migrant media use is a consequence of the individual stage of integration, different types of integration were identified by applying a hierarchical cluster analysis and then looking at what kind of media use habits these types showed. On the basis of the 2006 WDR data, this typology was replicated for the younger Turks in North Rhine-Westphalia. This replication will be shown in the results section after having taken a closer look at the theoretical framework of the typology, the strategies of acculturation, and the media use assumptions. 


\section{Theoretical framework}

The term integration in the context of migration and ethnic minorities is ambiguous. It has at least two different meanings in German: the whole process of interaction and confrontation of migrants in the (new) social context of the arrival nations and (particularly in the political part of the discussion) the assimilation of migrants in terms of cultural and societal adaptation of strangers (Pöttker, 2005: 27-30; Sackmann 2004: 2969; Vlasic, 2004: 16). In the context of international social science and anthropological migration research, it is not clarified further. A lot of concepts and terms are used to describe the situation of an ethnic minority which is confronted with a new social context and reacts in order to redefine its identity. Diaspora, ethnicity and ethnicization, dual and hybrid identity, strangeness, ethno-cultural position, and acculturation are only a few examples for terms used to describe the orientation between two contexts: The context of origin as well as the context of arrival (Alexander, 2004; Sinclair and Cunningham, 2000; Christiansen, 2004; Milikowski, 2000; Aksoy and Robins, 2003; Cohen, 1997).

This is not the place to systematize all terms and concepts of integration in the context of migration and media research. For the following analyses, the concept of acculturation strategies described by Berry (1997) will be used as a kind of down-to-earth approach which helps clarify the connections of two cognitive and attitude-related dimensions ${ }^{2}$ : the relation to the social contexts of origin on the one hand and the relation to the new social context of arrival on the other. He identifies four different strategies of social interaction for the non-dominant group (the ethnic/migrant minority): (1) Integration is the combination of both maintaining the cultural identity of origin and interacting with/ participating in the host society; (2) Assimilation is the non-willingness to maintain the cultural identity of origin and "seeking daily interaction with other cultures" (Berry, 1997: 9); (3) The alternative strategy to assimilation is separation, which means less interaction with the social context of arrival and a strong wish to maintain the cultural identity of origin; (4) Marginalization is defined as the lack of interest in both social contexts.

The essential feature of this concept is the postulated independence of the two dimensions. All four combinations of handling the two societal contexts are equitable - there is no a-priori-determination between participating in the host society and maintaining the social background of migration. This means the acceptance of developing a hybrid identity (Thompson, 2002: 410) or dual identity (Caspi, Adoni, Cohen and Elias 2002: 539) and the concession of more cultural autonomy for ethnic minorities by the host society. In a way, the understanding of integration 
in this concept is a contradiction to the melting pot model, which assumes a stronger assimilation of minorities (Sinclair and Cunningham, 2000: 14). The independence of the two dimensions is contradictory to the often heard argument that the use of migration media would lead to a 'media ghetto' and would harm the integration of migrants.

Media use of migrants in this theoretical framework is conceptualized as the main dependent variable. In contrast to the implicit media effect thesis in the public debate, we follow the principal ideas of the uses and gratifications perspective (Rubin, 2002). From this point of view and with respect to previous empirical findings, the media use of Turkish migrants in Germany is the result of multiple interactions between demographic variables (age, length of stay, citizenship), individual language skills and use, social interaction and political interest leading to individual stages of integration. These stages again result in different needs for information and therefore different patterns of media use (Weiss and Trebbe, 2001: 5). Hence, this paper is focused on the question whether individual states of integration and/or the pursuit of a distinctive acculturation strategy with respect to the dominant host society have significant effects on language-bound media use.

\section{Research questions and objective}

Against the background of the described research context and the theoretical framework, the following research questions can be posed: (1) Can different types of integration and/or assimilation with respect to their attitude towards the German society be described and identified? (2) If so, how are these different patterns of integration related to the society of origin? (3) Is there any evidence for different media use patterns within these types of integration? (4) And, finally, can empirical evidence be provided for effects of integration/acculturation strategies on the use of German and Turkish media? These questions will be addressed in the following section. But first, a short description of the sample of the WDR-study is provided in the method section.

Building upon the theoretical framework, the research objective can be expressed more precisely. The identification of types will not consist of considering the attitudes towards the societal and cultural context of origin. It will concentrate on the interaction of Turkish migrants with the German host society. Cluster analysis will be adopted to identify homogenous groups of similar interaction patterns within the German society. Variables that represent these types include: German citizenship, the intention to stay, language skills, political interest and integration, social interaction, need for information sources, and trust in German 
institutions. Afterwards, the significant profiles of the types will be described. Indicators will be demographic variables (sex, age, education), everyday language use, and German and Turkish media use. The third and last step of the analyses in this article will include the calculation of a set of linear regression models in order to provide evidence for causal effects of integration and acculturation strategies on language-bound media use.

\section{Method and sample}

The population of the 2006 survey (Attitudes and media use of young Turks in $N R W$ ) was defined as "persons from Turkish origin aged between fourteen and 49 in private households with a telephone book entry" (Enigma-GfK Medien- und Marktforschung, 2006). The sample was drawn on a basis of surname probability (Koss, 2002), stratified regionally as well as within the households. At least 503 interviews were completed. Thus, the sample is representative for the named population in North Rhine-Westphalia. Participants were asked for their preferred language for the interview and had the choice between a German speaking interviewer and a Turkish one. About half of the interviews (49 percent) were conducted in Turkish. Table 1 shows some basic data of the sample.

The questionnaire consisted of four main sections: media use, integration and identity, actual events and interest in politics. Only variables from the integration and identity section were used for identifying the integration types. In order to clarify the set of active variables ${ }^{3}$ for the cluster analysis, two factor analyses were carried out ${ }^{4}$. The first factor analysis concerned confidence/trust in eleven German institutions (authorities, police, labor unions, parties, schools, army, physicians, justice, hospitals, and social institutions). All variables were combined to the factor 'Trust in German institutions'. In the second factor analysis two more factors were identified. The factor 'Social interaction with Germans' was formed by two variables: acceptance of friendship between Turks and Germans and a positive point of view regarding marriage between Turks and Germans. The third factor 'political integration' combined two questions related to political representations of the Turks by German politicians ('German politicians care about people like me' and 'German politicians represent the interests of the Turkish minority in Germany').

Finally, the set of active variables for the segmentation via hierarchical cluster analysis consisted of eight dimensions. In addition to the three 
Table 1. Description of sample (Attitudes and media use of young Turks in NRW; WDR study, 2006).

\begin{tabular}{lc}
\hline Demographic variables & percentage $(\mathrm{n}=503)$ \\
\hline Age (mean) 30 & 17 \\
14 to 19 & 30 \\
20 to 29 & 35 \\
30 to 39 & 18 \\
40 to 49 & 100 \\
\hline Total & \\
\hline Gender & 52 \\
Male & 48 \\
Female & 100 \\
\hline Total & \\
\hline Education & 16 \\
Without any graduation & 39 \\
Elementary/primary school & 26 \\
Secondary school & 19 \\
University entrance diploma/degree & 100 \\
\hline Total &
\end{tabular}

factors five more variables were chosen as indicators for social interaction with the German society: (1) German language skills as a prerequisite for social interaction; (2) holding of the German citizenship or the wish to become naturalized; (3) Desire/plan to stay in Germany for a lifetime; (4) Interest for German politics, and (5) the quantity of information sources for German issues.

Following our theoretical conception this step is solely conducted with variables regarding the arrival context. The second step of the typology will be the description of the types identified in terms of demographic variables and media use. Finally, the relation between individual integration level and maintenance of the Turkish identity will be tested. In terms of multivariate cluster analysis these variables are passive dimensions within the procedure.

\section{Results: Integration types, acculturation strategies and media use}

Three types of integration, that is, attitudes towards and social interaction within the German society, were identified on the basis of the active variables and factors (Table 2$)^{5}$. 
Table 2. Types of integration among young Turks in NRW (WDR study, 2006) ${ }^{6}$.

\begin{tabular}{lccc}
\hline Active dimensions & $\begin{array}{c}\mathrm{A} \\
(\mathrm{n}=190)\end{array}$ & $\begin{array}{c}\mathrm{B} \\
(\mathrm{n}=193)\end{array}$ & $\begin{array}{c}\mathrm{C} \\
(\mathrm{n}=120)\end{array}$ \\
\hline German citizenship & $\varnothing$ & ++ & --- \\
Naturalization desired & +++ & +++ & --- \\
Plan to stay for a lifetime & +++ & --- & --- \\
Language skills German & ++ & $\varnothing$ & -- \\
Interest in German politics & + & + & --- \\
Political integration & + & - & - \\
Information sources for German issues & $\varnothing$ & + & --- \\
Trust in German institutions & + & + & -- \\
Social interaction & + & + & -- \\
Percentage in sample & $38 \%$ & $38 \%$ & $24 \%$ \\
Overall Attitude towards German soc. & Positive & Positive & Negative \\
Overall degree of integration & High & High & Low \\
Short label for further analyses & A $(I+)$ & $B(I+)$ & $C(I-)$ \\
\hline
\end{tabular}

Two of them could be described as multiply integrated. Type A (38 percent of the sample) has an above-average desire of becoming German citizen, wants to stay in Germany, and is quite proficient when it comes to speaking the German language (in comparison to the average of the whole sample). In addition, there a rather positive attitude toward social interaction and trust in German institutions can be noted. Type B (38 percent) is not much less integrated. The majority of this group carries German citizenship or desires it. This type is interested in German politics and appreciates social interaction between Turks and Germans in Germany. Unlike the two others, Type C (24 percent) is less integrated in terms of the indicators used in this analytical procedure: all values are below average. There are very low values for obtaining German citizenship, less concrete plans to stay in Germany, worse language skills, and a very small amount of interest in Germany and German issues. Length of stay in Germany did not prove to be a statistically significant marker for belonging to one of the three types.

All in all, we were able to label more than three quarters of the sample as integrated at an above-average level. There are differences in the dimensions of integration, especially as to the individual state of being or becoming a German citizen and in terms of having (or not having) plans to stay in Germany permanently. It is evident that 24 percent of the sample can be described as less or not integrated. In other words: there is an identifiable amount of active and young Turks in Germany, more precisely in NRW, who turn away from social interaction and participation in societal and political issues. 
In comparison to the typology carried out on the 2000 BPA data, a more clear-cut result was found in 2006 (Weiss and Trebbe, 2001: 4143). In the 2000 BPA study, six different types were found based on almost the same variables. Three of them were described as less integrated than the average member of the sample. The results are nevertheless consistent in terms of the number of integration types because two of the three less integrated groups included older members of the sample, this group of "senior migrants" not being part of the 2006-WDR-sample. Nevertheless, one difference between the two similar typologies persisted: the forerunner study consisted of three above-average integrated types, and all three showed no differences with regard to their (desired) citizenship and their desire or plan to stay in Germany permanently. This distinctive criterion within the more integrated types seems to work solely in the newer and younger sample of North Rhine-Westphalia.

\section{Demographic profiles}

Table 3 shows the demographic set of passive variables describing the three different types of integration. Although age is a significant factor

Table 3. Social characteristics (sex, age, education) and types of integration among young Turks in NRW (WDR study, 2006).

\begin{tabular}{lcccc}
\hline Passive dimensions & $\begin{array}{l}\mathrm{A}(\mathrm{I}+) \\
(\mathrm{n}=190)\end{array}$ & $\begin{array}{l}\mathrm{B}(\mathrm{I}+) \\
(\mathrm{n}=193)\end{array}$ & $\begin{array}{l}\mathrm{C}(\mathrm{I}-) \\
(\mathrm{n}=120)\end{array}$ & $\begin{array}{l}\text { Total } \\
(\mathrm{n}=503)\end{array}$ \\
\hline Sex & 47 & 57 & 53 & 52 \\
Male & 53 & 43 & 47 & 48 \\
Female & 100 & 100 & 100 & 100 \\
\hline Total & 30 & 29 & 32 & 30 \\
\hline Age** Mean & 19 & 21 & 8 & 17 \\
14 to 19 & 28 & 33 & 27 & 30 \\
20 to 29 & 36 & 27 & 49 & 36 \\
30 to 39 & 17 & 19 & 17 & 18 \\
40 to 49 & 100 & 100 & 100 & 100 \\
\hline Total & & & & \\
\hline Education & 13 & 17 & 19 & 16 \\
Without any graduation & 39 & 35 & 44 & 39 \\
Basic/primary school & 28 & 27 & 23 & 26 \\
Secondary school & 21 & 21 & 13 & 19 \\
University entrance Diploma/degree & 100 & 100 & 100 & 100 \\
\hline Total & & &
\end{tabular}

** $p \leq .05$ 
differentiating between the types, the differences between the groups are rather small ${ }^{7}$. The sample's average age is thirty years and the two highly integrated types have almost the same value (Type A: aged 30/Type B: aged 29). Only the third and less integrated type shows a higher mean age (32 years). The group of thirty to 39 year-olds is overrepresented (49 percent) in Type $\mathrm{C}$ in comparison to the other groups and the sample total (36 percent). Thus it can be said that there is still an effect of age on the integration state. Older people in general are less integrated than younger ones. This connection can also be found in a relatively young sample of Turkish people younger than 50 .

A few more socio-demographic differences between the groups can be identified, but none of them show a significant interdependence with the three integration types: Type A has a higher proportion of women than the average sample. Type $\mathrm{C}$ shows an overbalance of graduates of basic/ primary schools. Altogether, however, there is no clear demographic profile of the three types of integration. Except for age, the groups are very similar in terms of standard demographic variables.

\section{Acculturation strategies}

What acculturation strategies are dominant within the three integration groups? This question can be answered by investigating those dimensions of behavior that can take place with respect to both the origin and the host context. A very strong indicator for the dominant strategy of acculturation is everyday use of language (Moon and McLeod, 2003: 6). Table 4 shows the everyday use of Turkish and German languages based upon self-report. The figures are in some aspects astonishing ${ }^{8}$.

The two relatively higher integrated types A and B can be differentiated with respect to the two strategies of acculturation we mentioned. Type A clearly pursues the assimilative strategy. The percentage of Turkish migrants who speak mostly German is about one third of the group (31 percent). Type B more often pursues the integrative strategy (53 percent) by speaking the two languages complementarily and has a high proportion of mostly Turkish speaking young Turks (34 percent).

Even the less interactive and participating type $\mathrm{C}$ shows a comparatively high percentage of integrative language use as 39 percent of this group is using Turkish as much as German in everyday life. In addition, 15 percent of those who pursue an assimilative strategy of speaking only or even mostly German in everyday life. In conclusion, it can be argued that (1) the individual perspective of staying in Germany is strongly related to the combined use of the two languages and (2) there is empirical evidence for the two different attitudes regarding the cultural host context. Two groups with positive attitudes towards the German society 
Table 4. Bi-cultural language use and types of integration among young Turks in NRW (WDR study, 2006).

\begin{tabular}{lllll}
\hline Types & $\begin{array}{l}\mathrm{A}(\mathrm{I}+) \\
(\mathrm{n}=190)\end{array}$ & $\begin{array}{l}\mathrm{B}(\mathrm{I}+) \\
(\mathrm{n}=193)\end{array}$ & $\begin{array}{l}\mathrm{C}(\mathrm{I}-) \\
(\mathrm{n}=120)\end{array}$ & $\begin{array}{l}\text { Total } \\
(\mathrm{n}=503)\end{array}$ \\
\hline $\begin{array}{l}\text { Language use*** } \\
\text { Integrative, German und Turkish equal }\end{array}$ & 45 & 53 & 39 & 47 \\
Assimilative, Mostly German & 31 & 13 & 15 & 20 \\
Separative, Mostly Turkish & 25 & 34 & 45 & 33 \\
\hline Total & 100 & 100 & 100 & 100 \\
\hline Language skills*** & & & & \\
Integrative, German and Turkish & 65 & 53 & 45 & 55 \\
Assimilative, German better than Turkish & 12 & 10 & 8 & 10 \\
Separative, Turkish better than German & 23 & 35 & 43 & 32 \\
Marginalized, Both languages poor & 1 & 3 & 4 & 2 \\
\hline Total & 100 & 100 & 100 & 100 \\
\hline
\end{tabular}

*** $p \leq .001$

and institutions were found. One group is more assimilative in terms of abandoning the Turkish context through language use and the other is more integrative, that is, maintaining both the German and the Turkish social context.

Furthermore, language skills should be examined, as they are the prerequisite for the everyday language use and one of the active variables (as far as only German is concerned). The figures show that there is no equivalent dominance regarding the capability of using German. The intergroup differences are very small (between 12 and 8 percent for the assimilative strategy) and there is a linear tendency for a decreasing German skill from type A to C. But in all three groups, more than fifty percent are able to speak German as well as Turkish. Reconsidering the results shown in table 4, it can be concluded that, when alternatives for living in both contexts exist, more than one acculturation strategy is chosen, and evidently assimilation is not the first choice.

\section{Media use}

The proportion of the sample whose media use can be described as integrative adopting Berry's definition (1997) is relatively high, as 55 percent use German media as often as Turkish media (Table 5). This is somewhat more than what was found in the nationwide 2000 BPA Survey (50 percent, Weiss and Trebbe, 2001: 29). The percentage is neither lower in the sample of younger Turks nor decreased from 2000 until 2006: 17 percent 
Table 5. Media use (core use) and types of integration among young Turks in NRW (WDR study, 2006) $)^{9}$.

\begin{tabular}{lllll}
\hline Types & $\begin{array}{l}\mathrm{A}(\mathrm{I}+) \\
(\mathrm{n}=190)\end{array}$ & $\begin{array}{l}\mathrm{B}(\mathrm{I}+) \\
(\mathrm{n}=193)\end{array}$ & $\begin{array}{l}\mathrm{C}(\mathrm{I}-) \\
(\mathrm{n}=120)\end{array}$ & $\begin{array}{l}\text { Total } \\
(\mathrm{n}=503)\end{array}$ \\
\hline$T V$, Radio, Press & & & & 53 \\
Integrative media use German und Turkish & 56 & 55 & 53 & 53 \\
Assimilative media use German only & 20 & 18 & 13 & 17 \\
Separative media use Turkish only & 19 & 25 & 27 & 23 \\
No Core Use & 5 & 3 & 8 & 5 \\
\hline Total & 100 & 100 & 100 & 100 \\
\hline TV only & & & & \\
Integrative media use German und Turkish & 47 & 45 & 40 & 45 \\
Assimilative media use German only & 23 & 16 & 12 & 18 \\
Separative media use Turkish only & 24 & 32 & 36 & 30 \\
No Core Use & 6 & 6 & 11 & 7 \\
\hline Total & 100 & 100 & 100 & 100 \\
\hline
\end{tabular}

use only German-language media, 23 prefer only Turkish media, and 5 percent do not even have any core media use of television, radio or daily press. Looking at the three groups identified as types of integration, differences can be seen, though none of them are significant. There is a light slope in the so-called separative media use, the exclusive use of Turkish-language media, going from Type A (19 percent) to Type B (25 percent) to Type $\mathrm{C}$ ( 27 percent). Corresponding to that an above-average value could be noted for assimilative media use in terms of using only German-language media within the most integrated Type A (20 percent). In the less integrated group, Type $\mathrm{C}$, this percentage is much lower (13 percent). But at least all three groups are very similar in terms of combined media use: ranging from 56 percent (Type A) to 53 percent (Type C). At this point in the analyses, it seems very unlikely that there will be a strong connection between integration and German- and Turkishlanguage media use. But before moving on to the causal analysis, the bivariate exploration of television viewing will be examined.

In the case of the use of television, the most easily accessible mass medium in German and Turkish language, the differences between the types are somewhat stronger. The percentage of people who watch Turkish television exclusively is 30 percent in the whole sample. The most integrated Type A amounts to a proportion of 24 percent, the less integrated Type $\mathrm{C}$ to 36 percent, and differences are still not significant. The assimilative television use, that is, the use of German TV only, shows proportions similar to the general assimilative media use, both for the whole 
sample (18 percent) and for the three types of integration (between 12 percent, Type C, and 23 percent, Type A as well). The amount of integrative (combined) TV use is in all groups lower than integrative media use in general. This can be seen as a consequence of a greater autonomy of decision due to the availability of cable and satellite television in the Turkish language.

\section{Causal analyses}

In an effort to analyze this approach conclusively, two families of linear regression models were examined (Table 6) ${ }^{10}$. Language-bound media use is explained as an effect of the chosen acculturation strategy. In addition to that main predictor, language skill was controlled as a prerequisite for media access and age because of its significant relation to the identified types of integration. The main independent variable is an index of six variables coded in the same manner as language use shown in table $4^{11}$. The variables daily use of language, German citizenship, political interest, number of information sources regarding Turkey, number of information sources regarding Germany, and interaction with friends were each coded corresponding to the four acculturation strategies depending on whether there was an individual balance between the choice of acting in the Turkish and German context (integration) or an overbalance for the Turkish (separation) or the German context (assimilation); marginalization was coded, when none of the two contexts were chosen ${ }^{12}$. The indices of acculturation strategies were finally computed by adding up the number of equal strategies in all six variables. As a result, four independent variables were obtained which were used to calculate eight independent regression models - one for each acculturation strategy and each dependent variable.

The dependent variables are two summarized indices of the languagebound media use: One for the Turkish media television, press, radio and the Internet, and the other one in the same manner for the use of German-language media. Both indices were built by adding up the number of weekdays for the corresponding media use (self-assessment).

As a first result, the use of German-language media use is much better predictable by these models than Turkish media use. The average adjusted coefficient of determination $\left(R^{2}\right)$ for the quantity of German media use is about .33. This is a rather large amount of explanatory power for a media use model. The explanatory power of the regression models for the use of Turkish media is much smaller, ranging between .07 and .09. It is furthermore obvious that the capability of understanding Turkish is almost the only significant predictor for the use of Turkish media (within this set of independent variables). With one exception: Model II 
Table 6. Acculturation strategies and media use of young Turks in NRW: Linear regression models.

\begin{tabular}{|c|c|c|}
\hline \multirow[t]{2}{*}{ Independent variables* } & \multicolumn{2}{|c|}{ Dependent variables (BETA's) } \\
\hline & $\begin{array}{l}\text { Use of Turkish- } \\
\text { language media }\end{array}$ & $\begin{array}{l}\text { Use of German- } \\
\text { language media }\end{array}$ \\
\hline \multicolumn{3}{|l|}{ Model I } \\
\hline Age & \multirow{3}{*}{.26} & .13 \\
\hline Language skills (Turkish/German) & & .59 \\
\hline Acculturation strategy (Index): Integration & & .11 \\
\hline Adj. $\mathrm{R}^{2}$ & .07 & .32 \\
\hline \multicolumn{3}{|l|}{ Model II } \\
\hline Age & & .10 \\
\hline Language skills (Turkish/German) & .24 & .53 \\
\hline Acculturation strategy (Index): Assimilation & -.13 & .16 \\
\hline$\overline{\text { Adj. } R^{2}}$ & .09 & .34 \\
\hline \multicolumn{3}{|l|}{ Model III } \\
\hline Age & \multirow{3}{*}{.27} & .12 \\
\hline Language skills (Turkish/German) & & .53 \\
\hline Acculturation strategy (Index): Separation & & -.16 \\
\hline$\overline{\text { Adj. } R^{2}}$ & .07 & .34 \\
\hline \multicolumn{3}{|l|}{ Model IV } \\
\hline Age & \multirow{3}{*}{.27} & .12 \\
\hline Language skill (Turkish/German) & & .60 \\
\hline Acculturation strategy (Index): $\underline{\text { Marginalization }}$ & & -.12 \\
\hline$\overline{\text { Adj. } R^{2}}$ & .07 & .33 \\
\hline
\end{tabular}

*All given coefficients $p \leq .01$

shows a negative effect of the assimilative strategy of acculturation on the quantity of Turkish media use (Beta $=-.13$ ). But this can only be theoretically substantiated by the contradiction between the individual objective of pursuing assimilation and the exclusive use of Turkish media: It would simply make no sense. Age is not a significant predictor in any model for the use of Turkish media. The only working variable in all models for this dependent variable is the pre-conditional ability to access Turkish-language media.

The regression models for German media use are quite different. The explanatory power of dependent variables is much stronger. The whole (even small) set of variables shows significant effects on the use of German media. German language ability is the strongest predictor. The ac- 
culturation strategies show effects in each model. The effect of an integrative or assimilative strategy is positive: The more one pursues one of these strategies, the more German media are used. For separation and marginalization it is just the opposite. Thus it can be concluded that different strategies of acculturation lead to different strategies of media use. A high level of interaction and participation in the host society leads to a higher level of German media use. Finally, the regression coefficients for the integrative and the assimilative strategy have nearly the same value. Therefore, it can be argued that the impact of both strategies on the use of German-language media is evenly strong.

As assumed above, the role of age is also crucial for the explanation of the amount of German media use among young Turkish migrants. The effect is positive, so the quantity of German media use increases proportionally to the age of the persons interviewed in this survey. This could be an indicator for an increasing impact of the length of stay in Germany - even if the person is born in Germany.

In summary, it was found that (1) there is a significant impact of acculturation strategies - positive for the integrative and assimilative strategies, negative for the separative and isolative strategies - on the amount of German mass media use. (2) This impact is nearly not measurable for the amount of Turkish media use. In other words: There are different causes underlying the use of German and Turkish mass media by the young Turks in Germany. This will be discussed in the context of the theoretical framework and the preceding results in the final section.

\section{Discussion}

Regarding the first research question the findings show that a distinctive set of different integration types could be identified. In the first step of the analyses described here, two different types of young Turks were identified, both with high levels of interaction with and participation in the German societal context. The types are primarily different in their wish and plan to stay in Germany forever and their desire to become German citizens by naturalization. The two groups have the same share; together they represent three quarters of the sample. In contrast, a third type was found with negative (or at least a lack of positive) attitudes towards the German society. In terms of demographic variables this group was significantly older, but older in this sample means an age of 32 (Type C) in comparison to 30 (entire sample). This group represents about one quarter of the Turks in North Rhine-Westphalia below 50. With respect to the similar nationwide study in 2000 on behalf of the German government (BPA study, cf. Weiss and Trebbe, 2001), the structure of the typology was not surprising. In that study, two more types 
of less integrated Turks were identified. But both were representing groups of elderly people who were first generation migrants with lower levels of education and language capabilities.

When it comes to the identification of different strategies of maintaining the relation to the context of origin as posed in research question two, two different patterns of attitudes and behavior were found. There is obviously a high dependency between the types of integration and the daily use of German and Turkish. The examination of the combined use of the German and the Turkish language gave us evidence for two different underlying acculturation strategies within the integration types (A and B, see Table 4). One (type A) with a more assimilative strategy was found, which means that this group was in comparison to the other (type B) more often and exclusively speaking German. Type C showed - as expected - a more neglected use of German and a more exclusive use of the Turkish language. Taking language use as a strong indicator for a chosen acculturation strategy, it becomes clear that both the assimilative strategy of concentrating on the societal host context and the integrative strategy of maintaining the identity of origin exist and are detectable among so called high integrated young Turks.

In terms of the third research question, the presumption of different media use patterns of the integration types and in particular the existence of an isolating media ghetto for the less integrated Turks, no empirical evidence was found. In contrast to language use, no corresponding strong relationship between language bound media use and the attitude towards the German societal context. In this step of the analyses, tendencies of distinctive media use for the integration types were found, but significant interdependences were not. This is an interesting result against the background of the theoretical assumptions. At this point, it can be concluded that there are different acculturation strategies but no different media use patterns among so called high integrated Turkish residents of NRW. Does this mean that mass media use is more or less independent from the attitude towards the German or the Turkish context but highly correlated with the individual combination of the attitudes towards both contexts? The causal analyses of two dependent variables for Turkish resp. German media use provided the answer to that final research question.

The strategy of the third step was leaving the types behind and looking for causal effects on the amount of Turkish and German media use. If the bivariate analysis of the integration types encourage differentiation between two types of positive attitudes against the German social and societal context - an assimilative and an integrative acculturation strategy - this differentiation could be helpful in identifying effects on both Turkish and German media use. Significant causal effects of the accul- 
turation strategies on the use of German television, radio, press, and internet in combination with a strong effect of language skills as a precondition for media use and age were found (and this was known from the analytical step before). However, almost no corresponding effects on the use of Turkish media were found - maybe a support for the argument that the acculturation strategies are all deduced from a theoretical framework regarding the strategies of a non-dominant group (the Turks) in a larger dominant (German) social context. Nevertheless, there seems to be strong empirical evidence for stating more or less independence of the use of Turkish media by young Turks from the integration status as well as from the acculturation strategy towards the majority context.

To summarize, it can be state (1) that a positive or negative attitude against the host context does not admit a prediction of the strategy of maintaining the identity of origin, both strategies - retaining and leaving behind - are possible and empirically identified for this sample of young Turks in NRW. Furthermore it can be concluded (2) that media use is indeed a consequence of the integration status of a person but only in the sense of acculturation strategy which means the specific combination of attitudes against the host and the original context. For further research it would be reasonable to think about a more comprehensive typology of Turkish migrants, not only in terms of integration but also in terms of acculturation strategies.

\section{Notes}

1. This term was used irrespective of their citizenship: in other words, these might include German citizens or even third generation migrants.

2. Berry has a psychological approach of cognitive strategies. But similar classifications of attitudes and social behaviour towards the host society and the society of origin can be found in approaches of sociological integration (Esser, 2000; Sackmann, 2004) as well as in the mass communication context (Caspi et al., 2002; d'Haenens, 2003).

3. The term "active variables" is used for indicators which are used as criteria for identifying and building the groups. In contrast, a "passive variable" is used to describe the identified groups afterwards. While passive variables are not part of the segmentation process, active variables are.

4. Two principal component analyses with varimax rotation were performed. The first factor analysis explained 30 percent of variance with one factor (trust in German institutions). The two factors of the second analysis (social integration and political integration) explained 32 resp. 34 percent of variance. (Cronbach's Alpha at least .7 for all factors).

5. Hierarchical cluster analysis was performed (Ward method with squared Euclidean distance).

6. Plus- $(+)$ and Minus (-) are given to indicate deviations from sample value; $\varnothing$ indicates that the sample percentage represents no significant deviation; $+/-$ indicates a deviation from at least 5 up to 10 percent; $++/--$ indicates a deviation 
from 10 to 15 percent; $+++/---$ indicates more than 15 percent deviation from sample value.

7. ChiSquare-Tests for independency and T-Tests for independent samples of means were performed; significant indicates at least p?.05.

8. Please remind: Both type A and B represent above-average integrated groups, type $\mathrm{C}$ is the less integrated one. One of the main differences between $\mathrm{A}$ and $\mathrm{B}$ consists of having the German citizenship and the plan to stay for a lifetime. Type A is not disproportionately often a holder of the German citizenship but has a strong desire to obtain it and is planning to stay in Germany forever. Type B has a higher number of German Turks but does not have an above average frequency of people who want to stay in Germany

9. Core Use ("Stammnutzer"): Access to mass media at least 4 of the 7 days in an average week (self-assessment).

10. Multiple linear regressions were performed.

11. The variable set for the causal analysis is equal to the set of active variables of the conducted cluster analysis - as far as it was asked for both the German and the Turkish context.

12. Exception: For the variable "language use" no marginalization was identified.

\section{References}

Aksoy, A. and Robins K. (2000). Thinking across Space: Transnational television from Turkey. European Journal of Cultural Studies, 3(3), 343-365.

Alexander, J. C. (2004). Rethinking strangeness: From structures in space to discourses in civil society. Thesis Eleven, 79(1), 87-104.

Berry, J. W. (1980). Acculturation as varieties of adaptation. In A. Padilla (Ed.), Acculturation. Theories, models and some finding (pp. 9-26). Boulder: Westview.

Berry, J. W. (1997). Immigration, acculturation and adaptation. Applied Psychology. An International Review, 46(1), 5-34.

Bundesamt für Migration und Flüchtlinge (2005). Migrationsbericht 2005 [Migration report]. Berlin: Bundesamt für Migration und Flüchtlinge.

Caspi, D., Adoni, H., Cohen, A. A. and Elias, N. (2002). The red, the white and the blue. The Russian media in Israel. Gazette, 64(6), 537-556.

Christiansen, C. C. (2004). News media consumption among immigrants in Europe. The relevance of diaspora. Ethnicities, 4(2), 185-207.

Cohen, R. (1997). Global Diasporas: An Introduction. London: UCL.

Darkow, M. and Eckhardt, J. (1982). Massenmedien und Ausländer in der Bundesrepublik [Mass media and foreigners in the Federal Republic]. Media Perspektiven, 1982(7), 462-473.

Darkow, M., Eckhardt, J. and Maletzke, G. (1985). Massenmedien und Ausländer in der Bundesrepublik Deutschland [Mass media and foreigners in the Federal Republic of Germany]. Frankfurt am Main, Berlin: Metzner.

Eckhard, J. (1987). Ausländer als Zielgruppe der Massenmedien [Foreigners as a target group of the mass media]. In Bundeszentrale für politische Bildung (Ed.), Ausländer und Massenmedien. Bestandsaufnahme der Perspektiven [Foreigners and mass media. Stocktaking of the perspectives] (pp.93-96). Bonn: Bundeszentrale für politische Bildung.

Eckhardt, J. (1990). Massenmedien und Ausländer in Nordrhein-Westfalen [Mass media and foreigners in North Rhine-Westphalia]. Media Perspektiven, 1990(10), $661-674$. 
Eckhardt, J. (1996). Nutzung und Bewertung von Radio- und Fernsehsendungen für Ausländer [Use and evaluation of radio and television programs for foreigners]. Media Perspektiven, 1996(8), 451-461.

Eckhardt, J. (2000). Mediennutzungsverhalten von Ausländern in Deutschland [Media use among foreigners in Germany]. In H. Schatz, C. Holtz-Bacha and J.-U. Nieland (Eds.), Migranten und Medien. Neue Herausforderungen an die Integrationsfunktion von Presse und Rundfunk [Migrants and media. New challenges for the integration function of press and broadcast] (pp. 265-271). Wiesbaden: Westdeutscher Verlag.

Enigma-GfK Medien- und Marktforschung (2006). WDR - Einstellung und Mediennutzung junger Türken in NRW. Methodenbericht [Attitude and media use of young Turks in North Rhine-Westphalia. Methodological report]. Wiesbaden: Enigma-GfK Medien- und Marktforschung.

Gentürk, R. (2000). Mediennutzung der türkischen Migranten [Media use of Turkish Migrants]. In H. Schatz, C. Holtz-Bacha and J.-U. Nieland (Eds.), Migranten und Medien. Neue Herausforderungen an die Integrationsfunktion von Presse und Rundfunk [Migrants and media. New challenges for the integration function of press and broadcast media] (pp. 272-280). Wiesbaden: Westdeutscher Verlag.

Goldberg, A. (1998). Media Vielfalt vs. Media Ghettoisierung [Media diversity vs. media ghettoization]. Zeitschrift für Migration und soziale Arbeit, 1998(2), 35-41.

Koss, G. (2002). Namensforschung. Eine Einführung in die Onomastik [Name research. An introduction to onomastics]. Tübingen: Niemeyer.

Meier-Braun, K.-H. (2002). Migranten in Deutschland: Gefangen in Medienghetto [Migrants in Germany: Caught in the media ghetto]? Available (consulted January 9, 2007) at: http://www.swr.de/imperia/md/content/international/6.rtf

Milikowski, M. (2000). Exploring a model of de-ethnicization. The Case of Turkish television in the Netherlands. European Journal of Communication, 15(4), 443468.

Müller, D. K. (2000). Fernsehforschung ab 2000 - Methodische Kontinuität [Television research as from 2000 - methodological continuity]. Media Perspektiven, 2000(1), 2-7.

Pöttker, H. (2005). Soziale Integration. Ein Schlüsselbegriff für die Forschung über Medien und ethnische Minderheiten [Social integration. A key term for the research on media and ethnic minorities]. In R. Geißler and H. Pöttker (Eds.), Massenmedien und die Integration ethnischer Minderheiten in Deutschland [Mass media and integration of ethnic minorities in Germany] (pp. 25-44). Bielefeld: Transcript.

Rubin, A. M. (2002). The Uses-and-Gratifications Perspective of media effects. In J. Bryant and D. Zillmann (Eds.), Media Effects: Advances in theory and research (pp. 525-548). Mahwah, NJ: Lawrence Erlbaum.

Sackmann, R. (2004). Zuwanderung und Integration. Theorien und empirische Befunde aus Frankreich, den Niederlanden und Deutschland [Immigration and integration. Theories and empirical findings from France, the Netherlands and Germany]. Wiesbaden: Westdeutscher Verlag.

Schneider, B. and Arnold, A.-K. (2006). Die Kontroverse um die Mediennutzung von Migranten: Massenmediale Ghettoisierung oder Einheit durch Mainstream [The controversy about the media use of immigrants: Media ghettoization or unity through mainstream media]? In R. Geißler and H. Pöttker (Eds.), Integration durch Massenmedien. Mass Media-Integration. Medien und Migration im internationalen Vergleich. Media and Migration: A Comparative Perspective (pp. 93119). Bielefeld: Transcript. 
Simon, E. and Kloppenburg, G. (2006). Das Fernsehpublikum türkischer Herkunft Programmerwartungen, Fernsehnutzung und Einstellungen [The television audience of Turkish origin - program expectations, television use and attitudes]. In WDR (Ed.), Zwischen den Kulturen. Fernsehen, Einstellungen und Integration junger Erwachsener mit türkischer Herkunft in Nordrhein-Westfalen. Ergebnisse der Medienforschung August/September 2006 [Between cultures. Television, attitudes and integration of young adults with Turkish origin in North Rhine-Westphalia. Results of media research August/September 2006] (pp. 16-31). Köln: WDR.

Sinclair, J. and Cunnigham, S. (2000). Go with the Flow. Television and New Media, $1(1), 9-29$.

Thompson, K. (2002). Border crossings and diasporic identities: Media use and leisure practices of an ethnic minority. Qualitative Sociology, 25(3), 409-418.

Trebbe, J. (2003). Mediennutzung und Integration. Eine Integrationstypologie der türkischen Bevölkerung in Deutschland [Media use and integration. An integration typology of the Turkish population in Germany]. In W. Donsbach and O. Jandura (Eds.), Chancen und Gefahren der Mediendemokratie [Chances and threats for media democracy] (pp. 417-430). Konstanz: UVK.

Trebbe, J. and Weiss, H.-J. (2001). Mediennutzung der türkischen Bevölkerung in Deutschland. Eine Umfrage des Presse- und Informationsamtes der Bundesregierung [Media use of the Turkish population in Germany. A survey on behalf of the Information office Germany]. Nord-Süd aktuell, 15(4), 633-644.

Trebbe, J. and Weiss, H.-J. (2006). Integration und Mediennutzung - Eine Typologie junger Erwachsener mit türkischer Herkunft in Nordrhein-Westfalen [Integration and media use - a typology of young adults with Turkish origin in North RhineWestphalia]. In WDR (Ed.), Zwischen den Kulturen. Fernsehen, Einstellungen und Integration junger Erwachsener mit türkischer Herkunft in Nordrhein-Westfalen. Ergebnisse der Medienforschung August/September 20062006 [Between the cultures. Television, attitudes and integration of young adults with Turkish origin in North Rhine-Westphalia. Results of the media research August/September 2006] (pp. 32-41). Köln: WDR.

Vlasic, A. (2004). Die Integrationsfunktion der Massenmedien. Begriffsgeschichte, Modelle, Operationalisierung [The integration function of mass media. Concept, history, models, operationalization]. Wiesbaden: VS Verlag.

Weiss, H.-J. (2002). Medienghetto - Nutzen türkische Migranten hauptsächlich türkische Medien [Media ghetto - do Turkish Migrants mainly Turkish media]? Tendenz, 2002(1), 11.

Weiss, H.-J. and Trebbe, J. (2001). Mediennutzung der türkischen Bevölkerung in Deutschland [Media use of the Turkish population in Germany]. Potsdam (unpublished research report).

Weiss, H.-J. and Trebbe, J. (2002). Mediennutzung und Integration der türkischen Bevölkerung in Deutschland. Ergebnisse einer Umfrage des Presse- und Informationsamtes der Bundesregierung [Media use and integration of the Turkish population in Germany. Results of a survey on behalf of the information office of Germany]. In K.-H. Meier-Braun and M. A. Kilgus (Eds.), Integration durch Politik und Medien? 7. Medienforum Migranten bei uns [Integration by politics and media? 7. Media forum Migrants with us] (pp. 45-48). Baden-Baden: Nomos.

Windgasse, T. (2006). Die Radionutzung der türkischstämmigen Bevölkerung im Kontext anderer Medien [Radio use of the Turkish population in the context of other media]. In WDR (Ed.), Zwischen den Kulturen. Fernsehen, Einstellungen und Integration junger Erwachsener mit türkischer Herkunft in Nordrhein-Westfalen. Ergebnisse der Medienforschung August/September 2006 [Between the cultures. 
Television, attitudes and integration of young adults with Turkish origin in North Rhine-Westphalia. Results of media research August/September 2006] (pp. 5663). Köln: WDR.

Zentrum für Türkeistudien. (1996). Medienkonsum der türkischen Bevölkerung in Deutschland [Media consumption of the Turkish population in Germany]. Essen: ZfT.

Zentrum für Türkeistudien. (1997). Kurzfassung der Studie zum Medienkonsum der türkischen Bevölkerung in Deutschland und Deutschlandbild im türkischen Fernsehen [Short version of the survey of media use of the Turkish population in Germany and the German image on Turkish television]. Essen: ZfT. 